\title{
Offer Opportunities of Levelling Online Courses for Latvia
}

\author{
Vita Balikova \\ Riga Technical University, Azenes iela 12, Riga, LV1048, Latvia, vita.balikova@rtk.lv
}

\begin{abstract}
Currently, all European countries, including Latvian, there is a decrease of students' mathematical knowledge. As a result, universities and high schools face the challenge of filling the knowledge in mathematics among students. This has resulted in increasing the level of knowledge disparity in study groups. And experience shows that many students need extra - levelling courses. One of solution of such courses would be a free on-line levelling courses.
\end{abstract}

Key words: levelling course, e-learning, open educational resources, online education, massive open online course (MOOC).

\section{INTRODUCTION}

Study in the first year is a period of adaptation of the students in the new educational environment. A significant increase in the amount of information students need to learn in one session is a serious problem for first-year students. In a lesson in school pupils usually study new material for an average of twenty minutes, the new information in the university student should take during the whole session. Problems encountered by students learning new material also due to the high level of abstraction inherent in the concepts, terms, for example, in higher mathematics. Most of the terms and claims sections of higher mathematics can not to be found in the interpretation of the world. But they are necessary for the internal needs of mathematics, as they will be used in future for the theory, and the solution of practical problems to be used indirectly. In recent years to these difficulties added one more problem: occurrence of students with insufficient knowledge of basic mathematics. The number of students who can not add fractions, disclose brackets, deal with integers, each year gets bigger. . This has resulted in increasing the level of knowledge disparity in study groups. This leads to a need for a extra - levelling course in mathematics.

In addition, at this time we live in a reform in the system of secondary and higher education, which is associated with the correction of educational programs. This leads to a greater diversity of quality and depth of mathematical training graduates.

\section{MATERIALS AND METHODS}

Situation in Latvia

Latvian students' average achievement in mathematics (482 points) is below the OECD (Organisation for Economic Co-operation and Development - Organisation for Economic Cooperation and Development - OECD) country average performance (496 points) and below the EU average performance (491), only a few EU countries (Lithuania, Greece, Bulgaria, Romania) achievements were even lower. Latvian overall progress of all students of mathematics competence since 2003 practically unchanged.

OECD PISA (Programme for International Student Assessment of the OECD) in 2006 and PISA 2009 will no longer show the Latvian education quality average growth, as demonstrated by the OECD program for the first cycles and other international comparative studies of education quality, such as the IEA TIMSS. Latvian is a relatively small primary school with good and outstanding achievement in reading, mathematics and science, and their number continues to decline. It would seriously hamper national development documents, the goals of science, technology and other areas. More there is a tendency to accelerate work with weaker students, which, of course, are also important primary in the final period. Our old schoolchildren's performance dependency on family welfare, home access to educational and cultural resources, compared to many other countries, is not big and it has a tendency to decrease. So the Latvian educational institutions in some extent able to compensate the negative factors. [6], [7], [8].

14th December 2012 on Faculty of Physics and Mathematics (FPM) of Latvian University (LU) was found Natural Science and Mathematics Education Centre of FPM LU established to provide a bridge between the University and the school, working with the talented students of science and mathematics teachers as well as finding new talent. It was created within project "Science and Mathematics". The newly established center tasks is to encourage young people's interest in science and math, to encourage innovation to enter the mainstream education system, continuity and collaboration between general education and higher education, promote science students and the general public, but also in strengthening the research activities in general education. [3], [4]

The Natural Science and Mathematics Education Centre of FPM LU is founded for work with gifted children, so there's no work with unsuccessful in mathematics.

At website "macibuvideo.lv" is available explanations and analysis of previous year school 
exams in video. In "Macibuvideo.lv" are placed short movies, where are simply explains of the laws and tasks solving. Students, teachers, parents and other interested peoples for free are available in nearly 200 training videos in mathematics, physics and chemistry for the secondary school classes. Movies stock is added regularly, gradually covering the entire content of the school curriculum in physics, chemistry and mathematics.

"Everyone in the school, teaching their subjects, we arrived at the need for a resource that allows you to be in several places at the same time. It also started to develop an educational video that has gained popularity in our and other students as well as teachers. Towards Mathematics and Physics 12th class exams this year, we are happy to see that "macibuvideo.lv 'attendance increased sharply. past week the number of unique users per day has doubled from 200 to 400 and has tripled in the time that visitors spend on average on our site., we aim to benefit materials many people as possible, so try to keep them available for free in the future, "says actor and Mathematics video creator Kalis.

"Macibuvideo.lv" has created in 2011 by three members of the "Mission Possible" - Martins Kalis, Gatis Narvaišs and Karl Kravis. "Macibuvideo.lv" goal is to help students understand mathematics and natural relationships, with high-quality video and task inventories in Latvian language appropriate for mathematics, physics and chemistry content in Latvian schools. [9]

The website "Macibuvideo.lv" has great explanatory videos, but there's no option to perform the tasks.

Internet - portal Skolas.lv is a multifunctional working environment for students and their parents, teachers, school administration and the education system as a whole. It helps to realize the high-quality and modern educational process, improves the availability of digital learning content, allows teachers to work more interesting and easier, but the administration of educational institutions to effectively manage these processes.

On Skolas.lv single electronic repository of training materials, which are nearly 2,500 different teaching materials and teaching aids printed bibliographic data are available. It is intended for all Latvian teachers and students (according to access rights). It is possible to search, select and insert learning tasks and learning resources, which can later easily be used in teaching.

Catalog is compiled in digital educational materials originating from other projects, such as "Natural Sciences and Mathematics Project", as well as valuable materials and LEIS SEDA project "Innovation in education 'new teaching materials and annotations Ministry of Education approved textbooks. [10]

This year eBig3 project was started. EBig3 is a synergetic approach with eLearning, TV and mobile technologies to promote new business developments. Project aims to create a network for cross-border research cooperation in technology enhanced learning (TEL) and to develop a strategy for educational business promotion service. Project will begin implementing the strategy and pilot a set of innovative learning solutions for inclusive human resource development and to promote the spirit of entrepreneurship in border regions.

The project will combine three kinds of TEL in a complementary way:

- eLearning-mainly computer and/or internetbased learning;

- $\quad$ tLearning-TV based learning;

- mLearning-learning with a use of mobile devices; to produce an effective $\&$ innovative crossmedia learning delivery system (eBig3) that goes beyond traditional web-based learning approaches.

The system will combine a wide coverage of TV technology and a wide accessibility of mobile technology with the capacity and flexibility of broadband. This will allow a learner to use a single delivery channel at a particular time (depending on availability and preferences) or a complementary combination of two or three delivery channels thus supporting learning anywhere any time paradigm. The work on the project solution includes integration of technical issues for cross-media learning content delivery, refinement of pedagogic considerations, development of shared understanding of target user learning contexts in border areas, production of learning content \& organizing course pilots. [11], [12], [13], [14]

Latvian most popular platform called e-learning environment Moodle is. Moodle is an open source software designed course management system. Moodle software itself is free and requires a standard server configuration, the installation can be performed by any server administrator. Another issue is the Moodle platform customization specific needs of the organization and technical support. Also, think about the Moodle user training, user support and administration. [15]

Some of universities of Latvia, for example, LU offer leveling course for own students. This courses are available in e-learning form to. [18]

The situation outside the Latvia

A massive open online course (MOOC) is an online course aiming at large-scale participation and open access via the web. MOOCs are a recent development in distance education and often use open educational resources. Typically they do not offer academic credit or charge tuition fees. Only about $10 \%$ of the tens of thousands of students who may sign up complete the course. [24]

MOOCs originated about 2008 within the open educational resources (or OER) movement. Many of the original courses were based on connectives' theory, emphasizing that learning and knowledge emerge from a network of connections. 2012 became "the year of the MOOC" as several well-financed providers, associated with top universities, emerged, including Coursera, Udacity, and edX.[25] Other 
universities scrambled to join in, as did more established online education providers such as Blackboard Inc, in what has been called a "stampede." Dozens of universities in Canada, Mexico, Europe and Asia have announced partnerships with the large American MOOC providers. [24][26]

Features associated with early MOOCs, such as open licensing of content, open structure and learning goals, and connectivism may not be present in all MOOC projects.

The short lecture format used by many MOOCs developed from "Khan Academy's free archive of snappy instructional videos. The website supplies a free online collection of more than 4,000 micro lectures via video tutorials stored on YouTube teaching mathematics, history, healthcare, medicine, finance, physics, chemistry, biology, astronomy, economics, cosmology, and organic chemistry, American civics, art history, macroeconomics, microeconomics, and computer science. [17] Khan Academy launched a computer science module in September 2012. Khan Academy has delivered over 240 million lessons. [16]

Analysts in the UK conducted a study of the state of the level of mathematics for first year students (over 10 years) and found steady downward trend of their level of knowledge and the establishment of the center responded to support students with poor school preparation. Here, students can fill in the gaps of school knowledge, previously ascertained exactly which topics they need to repeat. This is - a kind of diagnostic and rehabilitation center 0 .

Almost every major world university has its own leveling courses in several subjects, including mathematics. [19]

The Khan Academy is a non-profit educational website created in 2006 by American educator Salman Khan, a graduate of MIT and Harvard Business School. With the stated mission of "providing a high quality education for anyone, anywhere".

\section{CONCLUSIONS}

Currently, all European countries, including Latvian, there is a decrease of students' mathematical knowledge. As a result, universities and high schools face the challenge of filling the knowledge in mathematics among students. This has resulted in increasing the level of knowledge disparity in study groups. And experience shows that many students need extra - leveling courses. Latvian, European and American universities offers such courses only for oun students, often at an additional cost.

Furthermore, most universities tend to offer the same courses to the same group of academically bestqualified young students and fail to open up to other types of learning and learners, e.g. non-degree retraining courses for adults or gap courses for students not coming through the traditional routes. This has not only impeded access for disadvantaged social groups and prevented higher enrolment rates but has also slowed down innovation in curricula and teaching methods, hindered the provision of training/retraining opportunities to increase skills and competency levels in the workforce and led to persistent mismatches between graduate qualifications and labour market needs. Graduate unemployment in many Member States is unacceptably high. [19]

Either way, Massive Open Online Courses (MOOC) is now widely discussed innovation in higher education offer in the world.

Course offerings are varied. However, in these projects courses are mostly in English, but some of them are already available for content translation into other languages.

Compared to traditional courses in MOOC courses is very high student dropout, only about $4-10 \%$ of the participants completed MOOC to the end. None of the distance learning courses free of charge has yet found a sustainable business model.

Currently MOOC is free of charge. The vendors is still looking and check for the options to make a profit with the help of this course - continuing to offer courses for free or at a relatively lower cost than the "classroom" courses.

Course accreditation is very slow and it is not clear how separate courses will be part of the overall process of obtaining qualifications. Most vendors currently MOOC not be granted credits or qualifications.

Latvia already has a joint course development experience - working together Riga Technical University, University of Liepaja, Latvian University of Agriculture, Daugavpils University, Kaunas University of Technology, the University of Siauliai and Utena labor market training center, a free access to distance education system eBig3 was established. [27] There are offered already 11 courses. The project manager Atis Kapenieks emphasizes that eBig3 model is used not only internet technologies, but also used TV and mobile phones. LTV7, regional television, on Saturdays, demonstrates eBig3 style movie. movie characters appear in different situations, which is an in-depth understanding of eBig3 film invites eBig3 rates, sending SMS from your mobile phone. SMS technology is also used to enrich the learning support and significantly reduce the high dropout of students.

Thus, the problem diversity of level of mathematical preparation of students can be solved by the introduction of a leveling course. One of solution of such courses would be a free on-line leveling courses. In the case of Latvia, the courses can be offered in the project eBig3.

It is many levelling courses. However, data on the use and effectiveness of those courses are not sufficiently. This leads to the need for research on the use and effectiveness of the course. 


\section{REFERENCES}

[1] The Centre for Innovation in Mathematics Teaching [Online]. Available: http://www.cimt.plymouth.ac.uk/default.htm [Accessed: Feb. 27, 2013].

[2] Имас О.Н.. Пахомова Е.Г. Выравнивающий курс - одно из средств повышения качества образования (статья). Известия ТПУ. - 2004. -Том 307. - №7. - С. 159-161. [Online]. Available: http://cyberleninka.ru/article/n/vyravnivayuschiy-kurs-odnoiz-sredstv-povysheniya-kachestva-obrazovaniya [Accessed: Feb. 27, 2013]

[3] Ķ̄ilis R. Informatīvais ziṇojums „Par situāciju skolēnu sekmībā vispārējā izglîtībā” - 16.04.2012. - [Online]. http://izm.izm.gov.lv/upload_file/Normativie_akti/info_zinoju mi/2012/IZMizino_160412_sekmiba.539.pdf [Accessed: Feb. 27, 2013]

[4] Fizmat.lv - [Online]. http://fizmati.lv/skoleniem/ [Accessed: Feb. 27, 2013]

[5] Fizikas un matemātikas fakultātē tiks atklāts Dabaszinātṇu un matemātikas izglīî̄ibas centrs - [Online] http://www.lu.lv/zinas/t/9664/ [Accessed: Feb. 27, 2013]

[6] OECD Programme for International Student Assessment (PISA) [Online]. http://www.oecd.org/pisa/ [Accessed: Feb. 27, 2013].

[7] PISA data Alalysis Manual. SPSS second edition, 2009 [Online] http://browse.oecdbookshop.org/oecd/pdfs/free/9809031e.pdf [Accessed: Feb. 27, 2013].

[8] PISA 2006 Technical Report, 2006.

[9] Macību video [Online] - http://macibuvideo.lv/ [Accessed: Feb. 27, 2013].

[10] Skolas.lv [Online] - https://www.skolas.lv/Lapas/sakums.aspx [Accessed: Feb. 27, 2013].

[11] eBig3 [Online] http://www.latlit.eu/eng/running_projects/lliii183_ebig3/_gv/p rint_1 [Accessed: Feb. 27, 2013].

[12] LATLIT - [Online] http://www.latlit.eu/eng/running_projects/liiii183_ebig3 [Accessed: Feb. 27, 2013].

[13] Kapenieks A., Zuga B., Stale G., Kapenieks J. Jr., Jirgensons M., Ozolina A., Apinis B., Vitolina I., Gorbunovs A., Kudina I., Kapenieks J. Sn., Gulbis R., Treijere M., Slaidins I., Jakobsone-Snepste G., Gibze S., Kapenieks K., Tomsons D., Ulmane-Ozoliņa L., Letinskis J., Cakula S., Balode A., Blija T., Vilkonis R., Cibulskis G., Rutkauskiene D.. "eBig3": a new triple screen approach for the next generation of lifelong learning experience - [to be published]

[14] Kapenieks A., Zuga B., Stale G., Jirgensons M. An Eecosystem Driven Next Generation Life Long Learning Approach. IIMC International Information Management Corporation, 2012. ISBN: 978-1-905824-34-2, IST-Africa 2012 Conference \& Exhibition

[15] Balikova V., Ulmane I. The computer-based methods of training used in educational process. Balikova V., Ulmane I. Mācību procesā lietojamās datorizêtās apmācību metodes, //
Rīgas Tehniskās koledžas zinātniskie raksti „Augstākā profesionālā izglîtīiba teorijā un praksē", 10. sējums, izdevniecība „RTU”, Rīga, 2012 - 95. - 100. lpp.

[16] Khan Academy - [Online] http://www.khanacademy.org/contribute [Accessed: Feb. 27, 2013].

[17] Michels, Spencer (2010-02-22). "Khan Academy: How to Calculate the Unemployment Rate". PBS NewsHour. PBS. [Online] http://www.pbs.org/newshour/rundown/2010/02/khanacademy-how-to-calculate-the-unemployment-rate.html. [Accessed: Feb. 27, 2013].

[18] Metakurss: Izlīdzinošais kurss vidusskolas matemātikā. [Online] - http://estudijas.lu.lv/course/info.php?id=818 [Accessed: Feb. 27, 2013].

[19] Delivering On The Modernisation Agenda For Universities: Education, Research And Innovation. Communication from the Commission to the Council and the European Parliament, Commission Of The European Communities, Brussels, 10.5.2006 - [Online] lex.europa.eu/LexUriServ/LexUriServ.do?uri=COM:2006:020 8:FIN:en:PDF [Accessed: Feb. 27, 2013]

[20] Некряч Е.Н., Пахомова Е.Г., Подберезина Е.И. Выравнивающий курс как способ повышения эффективности образовательного процесса, Научнометодическая конференция, Томск 2011 - [Online] http://www.lib.tpu.ru/fulltext/c/2011/C09/111.pdf [Accessed: Feb. 27, 2013]

[21] Norises statistika un rezultātu raksturojums - [Online] http://visc.gov.lv/vispizglitiba/eksameni/statistika.shtml [Accessed: Feb. 27, 2013].

[22] Kamerāde D. Mācīšanās internetā par brīvu - kā tā ietekmēs augstskolas Latvijā?, $2013 \quad-\quad$ [Online] http://politika.lv/article/macisanas-interneta-par-brivu-ka-taietekmes-augstskolas-latvija [Accessed: Feb. 27, 2013]

[23] MOOCs at Edinburgh - [Online] http://www.ed.ac.uk/studying/postgraduate/online-distancelearning/programmes/mooc-edinburgh [Accessed: Feb. 27, 2013].

[24] Lewin T. Universities Abroad Join Partnerships on the Web. New York Times, 2013 - [Online] http://www.nytimes.com/2013/02/21/education/universitiesabroad-join-mooc-course-projects.html?_r=0 [Accessed: Feb. 27, 2013].

[25] Smith L. 5 education providers offering MOOCs now or in the future, $2012 . \quad-\quad$ [Online] http://www.educationdive.com/news/5-moocproviders/44506/ [Accessed: Feb. 27, 2013].

[26] Laura Pappano. The Year of the MOOC - The New York Times, 2012. - [Online] http://www.nytimes.com/2012/11/04/education/edlife/massive -open-online-courses-are-multiplying-at-a-rapidpace.html?pagewanted=1 [Accessed: Feb. 27, 2013].

[27] EBig3 - [Online] - http://ebig3.eu [Accessed: Feb. 27, 2013]. 